\title{
LOCAL FOOD SYSTEMS, SHORT SUPPLY CHAINS AND PERCEPTION OF LOCAL FOOD BY CONSUMERS: A REVIEW AND QUANTITATIVE RESEARCH
}

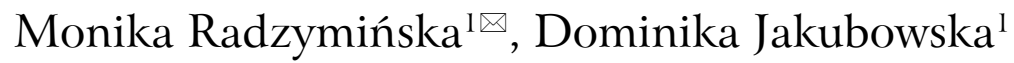 \\ ${ }^{1}$ University of Warmia and Mazury in Olsztyn, Poland
}

\begin{abstract}
The purpose of this paper was to depict a concept of local food systems and short supply chains as well as to determine how local food is perceived and to identify local food attributes of relevance for the marketing communication targeted at young people. This paper consists of two parts. The first one presents the concepts of local food systems and short supply chains based on the analysis of literature data. The second part describes the results of a quantitative study on the young consumers' perception of and willingness to buy local food. Based on an indirect technique, the study was carried out with a group of 155 Polish students. The questionnaire survey demonstrated that when characterizing local food, young consumers invoked the socioeconomic benefits related to its production. They paid less attention to the specific attributes of food products and to environmental benefits of their production and distribution, which might suggest that the initiatives undertaken to promote those products were poorly effective. The research results provide a useful source of knowledge for small local food businesses and policymakers engaged in supporting local food systems (especially public sector bodies and researchers).
\end{abstract}

Keywords: local food systems, short supply chains, attributes, consumer perception

\section{INTRODUCTION}

The growing consumer awareness of the consequences of their dietary choices and effects these choices have on their health results in an increasing importance of the trends linked to the greening of consumption, deconsumption and sustainable consumption (Rogala, 2015). By expressing their demands, the consumers contribute to increasing the importance of specialized/ dedicated production in addition to generic/standardized production (Storper and Salais, 1997; Follett, 2009) which promotes the manufacture of local food products with specific properties intended for a specific group of consumers. Considering various challenges of today's global economy, the development of local food systems is of particular concern. It contributes significantly to solving problems that result from ongoing globalization and is an important driver of sustainable development (Michalczyk, 2017). Industrialized countries witness a growing interest in local food expressed by both governmental bodies and local authorities. Local food systems are considered as an alternative to the global food production system, and are promoted within the context of sustainable food production (Kimura and Nishiyama, 2008; Arsil et al., 2014).

The literature emphasizes that the main barriers for local food purchasing are linked to a lack of effective marketing and distribution efforts, and therefore the development of effective marketing strategies is recommended (Byker et al., 2010; Dukeshire et al., 2011). The efficacy of initiatives undertaken to promote these products might be verified by identifying the benefits of local food consumption as perceived by the consumers (Heslop, 2007).

$凶$ PhD Eng Monika Radzymińska, Chair of Commodity Science, University of Warmia and Mazury in Olsztyn, Pl. Cieszyński 1, 10-7 19 Olsztyn, Poland, e-mail: mradz@uwm.edu.pl; https://orcid.org/0000-0003-0531-268X 
Therefore, the purpose of this paper was to depict a concept of local food systems and short supply chains as well as to determine how local food is perceived and to identify local food attributes of relevance for the marketing communication targeted at young people.

\section{THE CONCEPT OF LOCAL FOOD SYSTEMS AND SHORT SUPPLY CHAINS}

Measures taken in North America to develop local food systems are considered to be more radical than those in place in European Union countries. The European approach to local food systems development is characterized by a reformative style, with particular emphasis on changes in the policy, food security and rural development (Jokinen et al., 2009). The differences in support for and development of local food markets across UE member states have led to an uneven development of local food systems and diverse short supply chains. As a consequence, there are no uniform definitions of local food systems and short supply chains to be applied in all member states (Markuszewska et al., 2012). The European Committee of the Regions (Opinion..., 2011) urged the member states to identify the development objectives for the local food system in their own rural development strategies, and called the European Commission to accept definitions of local food systems and local food products, introduce new labeling, and define common symbols and identification systems of local products. It is recommended that the definitions be clear and easy in order to avoid complicated registration and control procedures. The report of the European Commission (Commission..., 2013) points out that the notion of local food systems suggests that the production, trading and consumption of food occur in a relatively small geographical area. However, neither the legislation nor the literature data are consistent about the threshold distance between the production and distribution place. In turn, short supply chains (Commission..., 2013) are characterized by a reduced number of intermediaries essential to provide the consumer with the final product. Beside a reduced number of intermediaries, the basic criteria in defining short supply chains are the shortest distance between producers and consumers as well as mutual understanding and communication between them (Markuszewska et al., 2012).

Local food systems are a quite new topic addressed in numerous scientific papers in the field of social economy and rural sociology. Local food systems are often presented as an alternative to global, industrial and conventional food production systems (NorbergHodge et al., 2007, Higgins et al., 2008; Mount, 2012; Lypchuk and Lypchuk, 2014). As emphasized in numerous studies, the local production system is associated with desirable environmental, social and economic effects (Chambers et al., 2007; Seyfang, 2007; Schönhart et al., 2008; McEachern et al., 2010; Farmer, 2012; Arsil et al., 2014). It is underlined that the development of local food systems is an important aspect in the context of economic development, prevention of rural marginalization, environmental protection (Norberg-Hodge et al., 2002; Morgan et al., 2006; Norberg-Hodge et al., 2007; Chambers et al., 2007), concern about global climatic changes (Blake et al., 2010), and health benefits resulting from the availability of low-processed food products (Pearson et al., 2011).

According to the European Committee of the Regions (Opinion..., 2011), local food systems bring environmental benefits through more sustainable production systems, reduced transport externalities (food miles, the distance food is transported between producer and consumer) and opportunities to create circular systems based on organic waste, residues and renewable energy. The creation of local markets for food products manufactured in very small amounts might contribute to sustaining biodiversity and development of disappearing varieties of fruits and vegetables and endangered species. Previous studies confirmed that short supply chains minimize carbon emissions (Jones, 2002). Arguments do appear, however, against the claims that the production of local food has a smaller environmental impact and that its consumption significantly improves consumer health compared to a diet based on non-local products (Edwards-Jones et al., 2008; Edwards-Jones, 2010). Due to scarce literature data, the need is emphasized for further studies on environmental benefits of local food production which should be made public (Coley et al., 2009).

Building trusted relationships between producers and consumers is pointed out as an example of social benefits brought by local food systems (Pearson et al., 2011). The trust is built upon real interactions and closeness rather than on abstract values (as it is the case in the global system). The producers feel responsible for the product they provide to the customer. In turn, the consumers consider the producers to be part of the local 
Radzymińska, M., Jakubowska, D. (2018). Local food systems, short supply chains and perception of local food by consumers: a review and quantitative research. J. Agribus. Rural Dev., 4(50), 435-444. http://dx.doi.org/10.17306/J.JARD.2018.00426

community. Food production in a local system helps controlling the product throughout its life cycle, thus increasing consumer trust in the products and reducing health risks thanks to the consumption of food from a known local provider who relies on organic cultivation and breeding (Hendrickson and Heffernan, 2002). As a result of building various relations with the consumers within a geographic area, a sense of pride and belonging can be built. Also, these processes strengthen social cohesion and foster a more sustainable social development (Markuszewska et al., 2012). Moreover, the actions related to the local food systems development, being a consequence of the basic production such as processing, distribution and retail, have a multiplication effect on the local community by generating employment opportunities (Commission..., 2013). Investing in local food systems would lead to economic recovery in underprivileged areas, better incomes for local producers and revived entrepreneurship (Opinion..., 2011).

Different initiatives for local product market development were established in European countries (Chambers et al., 2007), the US (Selfa and Qazi, 2005) and Canada (Knight, 2013), including: festive events, informative campaigns and events, partnerships, and trade events. The objective of these actions is to strengthen local and regional product brands and to build a relationship between consumers and manufacturers. Alternative Agro-Food Networks (AAFNs) operate in Europe as initiative hubs connecting local communities of farmers, processors, non-governmental organizations, consumers and retailers through the processes of production, distribution and consumption of high-quality food, including local food products (Goszczyński and Knieć, 2010, 2011; Psarikidou and Szerszynski, 2012). These networks might take different forms: consumer-producer partnerships (e.g. Community Supported Agriculture, CSA), direct sales (e.g. agricultural marketplaces, regular delivery of food orders to consumers), agroecotourism or public procurement, e.g. supplying food manufactured by local producers to schools and other public institutions (Markuszewska et al., 2012). CSA models are also well developed in the US where they are perceived as the main development drivers of local food systems (Polimeni et al., 2006). Food hubs operate in the US (Furmana and Papavasilioub, 2018) and are defined as value-based supply chains that aggregate, systematize, and centralize production and distribution at different scales, thus achieving economies of scale for farmers. Food hubs make it possible for many producers to gain entry into new larger-volume markets that boost their income and provide them with opportunities for scaling up production. Innovative distribution systems are put into practice in the development and implementation of measures taken to increase the availability of local food, e.g. online sales and innovative communitybased food retail outlets, such as the True Food Co-op in United Kingdom (Reading, Berkshire) (Pearson et al., 2011). It is emphasized that short chain supply systems are not the only strategy of local food distribution and might work together with a traditional supply chain, i.e. supermarket sale points, provided that the origin of food is clearly indicated (Penney and Prior, 2014). In this kind of sale, however, producers and consumers are unable to communicate directly with each other.

Launched in 1989 in Italy, Slow Food is an international social movement whose objectives include the protection and promotion of local products (Chrzan, 2004). It is engaged in activities such as encouraging biodiversity protection, development of local and regional agriculture, maintaining regional and national traditions, upholding culinary traditions, and developing the local identity. This network is strongly supported by restaurant chefs around the world, scientists and culinary journalists (Wiśniewska, 2012). Communities supporting the idea of locavore are established in the US and Western Europe. In line with the locavore ideology, local products are a healthier and more sustainable alternative to highly processed foods. Locavore enthusiasts believe that buying products from the neighborhood is a way to reduce adverse environmental impacts. Based on this trend, the concept of food miles arose, describing the distance traveled by food between producer and consumer. The information about food miles might be found in some retail shops as a part of product description (Rogala, 2014).

In Poland, local, regional and national initiatives undertaken to identify and promote high-quality local products take the form of festive events, festivals or best product competitions. An important national initiative identifying and promoting culinary heritage products is the best regional and local food product competition and the best regional and local dish competition (Our Culinary Heritage) organized by the Polish Chamber of Regional and Local Products and the Union of Voivodeships of the Republic of Poland. Moreover, actions are taken to promote local products through education 
in farms who joined the Polish Network of Educational Farms. The topics of educational activities for children and adolescents include the processing of raw materials produced on farms, local cuisine, ecology and meal preparation customs. It is vital to educate children and adolescents on these matters, in order not only to develop the taste of future consumers, but also to strengthen the importance of agriculture and traditional culture (Kieljan, 2015).

The prerequisite for further development of local food systems and short supply chains is the cooperation and wide partnership in the elaboration of common strategies for the development of the local food sector.

\section{PERCEPTION OF LOCAL FOOD BY YOUNG CONSUMERS: RESULTS OF AN ORIGINAL STUDY}

\section{Subject and methodology}

A quantitative pilot study was conducted to identify the attributes of local food which are important in the marketing communication targeted at young consumers. Based on an indirect technique, the survey was carried out in 2017 with 155 Polish students aged 20-25 living in the Warmia and Masuria region. The test sample was selected in a convenient way. The survey questionnaire was based on the original (modified) interview questionnaire (Radzymińska, 2016). It included statements referring to the perception of local food attributes ( 8 items) and the declared intention to buy this type of food products if available on the market ( 3 items). The respondents referred to the statements by expressing their approval or disapproval with a 7-point Likert scale, with 1 meaning "strongly disagree" and 7 meaning "strongly agree."

The results were analyzed statistically using Statistica 13.1. The following basic statistics were determined: mean $(x)$, standard deviation (SD) and median $(M)$. Additionally, the relationship between the perceived attributes of local food and the declared behavioral intention to buy it was analyzed with a correlation analysis at a significance level of $p=0.05$.

\section{RESULTS AND DISCUSSION}

The benefits brought by the purchase of locally made food products include both their intrinsic attributes (appearance, freshness, taste, health properties, authenticity) and extrinsic attributes such as supporting the local economy and agriculture; preserving arable lands and food security; reduced use of pesticides; shortening the distance traveled; lower energy consumption; and better treatment of workers and animals (Chambers et al., 2007; Adams and Salois, 2010; Marenick et al., 2010; Onozaka and Mcfadden, 2011; Pearson et al., 2011).

The results of the study on the perception of local food by young consumers are presented in Table 1. The perception was focused on two groups of values:

- product attributes: organoleptic features, guaranteed high quality, an all-natural composition resulting from the reduction or elimination of allowed additives (preservatives), traditional processing methods, low processing levels,

- altruistic values: environmental benefits resulting from such aspects as the distribution method, as well as socioeconomic benefits linked to supporting the local economy.

It was noted that local foods were considered to be better than highly processed mass-market products (mean $=5.32, M=5$ ). According to the respondents, local food is similar to traditional Polish food in terms of taste, aroma and appearance (mean $=5.23, M=5$ ). Moreover, this kind of food is characterized by: a smaller amount of additives and preservatives compared to other products available in the market (mean $=4.95$, $M=5$ ); traditional processing methods (mean $=4.73$, $M=5)$; guaranteed quality (mean $=4.77, M=5)$; and low processing levels (mean $=4.68, M=5$ ).

As shown, in the hierarchy of features attributed to local food, the altruistic values associated with socioeconomic benefits for the local economy were ranked the highest. When considering local food products, the respondents focused on their manufacturing impacts on the local economy (mean $=5.50, M=6$ ), rather than on their environmental impacts (mean $=4.94, M=5$ ).

The results showed a positive emotional attitude of consumers towards local food products across all product attributes studied. Nevertheless, local foods were definitely not considered in terms of product value $(M=5)$. Instead, young consumers associated local food with socioeconomic benefits $(M=6)$. When comparing these figures with the results of a survey conducted with buyers of local food in specialized stores (Radzymińska, 2016), it can be concluded that young consumers pay less attention to product attributes and environmental 
Radzymińska, M., Jakubowska, D. (2018). Local food systems, short supply chains and perception of local food by consumers: a review and quantitative research. J. Agribus. Rural Dev., 4(50), 435-444. http://dx.doi.org/10.17306/J.JARD.2018.00426

Table 1. Local food attributes and the intention to buy according to respondents

\begin{tabular}{llll}
\hline \multicolumn{1}{c}{ Variables } & $x$ & SD & $M$ \\
\hline Product attributes & & & 5 \\
it is of higher quality than other products available in the market & 5.32 & 1.19 & 5 \\
it is similar to traditional Polish food in terms of taste, aroma and appearance & 5.23 & 1.16 & 5 \\
it is manufactured using old traditional methods & 4.73 & 1.30 & 5 \\
it contains less additives and preservatives than other products available in the market & 4.95 & 1.26 & 5 \\
it is processed to a small extent & 4.68 & 1.19 & 5 \\
it is of guaranteed quality & 4.77 & 1.27 & 6 \\
Altruistic values & 5.50 & 1.06 \\
its processing is beneficial for the region and generates employment opportunities & 4.94 & 1.28 & 5 \\
it is less harmful to the environment (lower transport costs) & & 5.31 \\
Intention to buy & 5 \\
I intend to buy meat and meat products from small local manufacturers in the future & 5.00 & 1.31 \\
I intend to buy bakery from small local manufacturers in the future & 5.04 & 1.40 & 5 \\
I intend to buy dairy products from small local manufacturers in the future & 4.99 & 1.37 & 5 \\
\hline
\end{tabular}

Source: own research.

benefits linked to the production and distribution of this type of food. Based on other data on Polish consumers, it can be concluded that both buyers and non-buyers of local food believe it to be fresher, healthier and tastier than food transported over larger distances. The advantages of local products related to the degree of processing and environmental benefits were cited far less frequently (Rogala, 2014). In turn, Żakowska-Biemans et al. (2017) noted that in the conceptualization of local food, Polish consumers most often refer to product attributes; but above all, they associate local food with support for local economy, as reflected in the motives behind their purchasing decisions. The results of a segmentation research (Radzymińska, 2016) conducted with Polish consumers purchasing food in specialized stores suggest that local products are chosen primarily because the buyers are convinced of their high quality which is due to a natural composition, health properties, nutritional value, low degree of processing, authenticity, traditional processing methods and cultivation in an unpolluted environment. In two consumer segments identified, altruistic considerations related to support for the local economy were an important factor in selecting local food. Moreover, it was noted that altruism may be underpinned by the desire to reap personal benefits from product attributes.

Results of other surveys demonstrate that local food is perceived as safer and of better quality than conventional food (Murdoch et al., 2000), and is believed to be beneficial for health (Onozaka et al., 2010). In turn, in a study by Roininen et al. (2006), local foods were perceived as supporting the economy and associated with short supply chains, freshness and guaranteed origin. In another study, they were reported to be perceived in the context of environmentally-friendly products (Selfa and Qazi, 2005; Brown et al., 2009; Pearson et al., 2011). According to a study by Knight (2013), product attributes are ranked higher than social issues in the hierarchy of benefits perceived by the consumers. In turn, Haas et al. (2013) indicated that local products had a strong social dimension, represented by the desire of belonging to a local community, whereas their environmental attributes were ranked much lower than e.g. these of organic food.

As shown by the study (Table 1), the respondents (young consumers) declared (though hesitantly, $M=5$ ) 
Radzymińska, M., Jakubowska, D. (2018). Local food systems, short supply chains and perception of local food by consumers: a review and quantitative research. J. Agribus. Rural Dev., 4(50), 435-444. http://dx.doi.org/10.17306/J.JARD.2018.00426

Table 2. Relations between local food attributes and the declared intention to buy

\begin{tabular}{|c|c|c|c|}
\hline \multirow{2}{*}{ Variables } & \multicolumn{3}{|c|}{ Intention to buy } \\
\hline & $M$ & $B$ & $D P$ \\
\hline \multicolumn{4}{|l|}{ Product attributes } \\
\hline it is of higher quality than other products available in the market & $0.49 *$ & $0.42 *$ & $0.52 *$ \\
\hline it is similar to traditional Polish food in terms of taste, aroma and appearance & $0.41 *$ & $0.41 *$ & $0.52 *$ \\
\hline it is manufactured using old traditional methods & $0.36^{*}$ & $0.40 *$ & $0.44 *$ \\
\hline it contains less additives and preservatives than other products available in the market & $0.28 *$ & $0.29 *$ & $0.36^{*}$ \\
\hline it is processed to a small extent & $0.30 *$ & $0.30 *$ & $0.20 *$ \\
\hline it is of guaranteed quality & $0.33 *$ & $0.41 *$ & $0.31 *$ \\
\hline \multicolumn{4}{|l|}{ Altruistic values } \\
\hline its processing is beneficial for the region and generates employment opportunities & $0.26^{*}$ & $0.33^{*}$ & $0.34 *$ \\
\hline it is less harmful to the environment (lower transport costs) & $0.31 *$ & $0.42 *$ & $0.45^{*}$ \\
\hline
\end{tabular}

$M$ : meat and meat products, $B$ : bakery products, $D P$ : dairy products

*Statistically significant $(p<0.05)$

Source: same as in Table 1.

their intent to buy meat and meat products (mean $=5.0$ ), bakery products (mean $=5.04)$ and dairy products (mean $=4.99)$ from local producers once available in the market. This study determined the relationship (significance and strength of dependence) between the perceived attributes of local food and the declared intention to buy. Based on the determined bilateral correlation coefficients between the variables (Table 2), it was demonstrated that all attributes surveyed were statistically significantly related (at $p<0.05$ ) to the intention to buy local food. The calculated correlation coefficients indicated a strong, average and weak correlation between specific variables. It was noted that the intention to purchase (all of meat, bakery and dairy products) was most strongly correlated (at $p<0.05$ ) with egoistic values such as: higher quality of local products compared to other market products $(r=0.49, r=0.42, r=0.52$, respectively); organoleptic properties $(r=0.41, r=0.41$, $r=0.52$, respectively); and traditional processing $(r=$ $0.36, r=0.40, r=0.44$, respectively). On the other hand, the analysis of altruistic values showed that the perception of socioeconomic benefits brought by the production of local food had the lowest statistically significant impact (at $p<0.05$ ) on the declared intention to purchase this type of food.
As shown by literature data, not all attributes of local food are reflected in the factors affecting purchase decisions. Megicks et al. (2012) synthesized the attributes resulting from their qualitative investigation into factors, and proposed the following framework to explain the motivation behind purchasing local food: intrinsic product quality, local support and provenance, ethical sustainability and shopping benefits. In their model, intrinsic product quality and local support and provenance were significant. The authors indicated that the ethical sustainability dimension of local food shopping did not positively affect consumer purchases in this market. Memery et al. (2015) demonstrated in their study that shoppers purchase local food more frequently in order to provide local support rather than due to intrinsic product quality. Some other studies showed that quality, including health-promoting properties, convenience, environmental and social issues (Selfa and Qazi, 2005; Onozaka et al., 2010; Onozaka and Mcfadden, 2011) and engagement in the relations with farmers and food producers based on mutual trust (Marsden et al., 2000) are the motivations for buying local products. Some authors (Brown et al., 2009; Nurse et al., 2010) indicate that the consumers selflessly choose "sustainable food." 
The role of socio-demographic variables in explaining the choice of local food is still under discussion in the literature. It is suggested that the rural population (Brown, 2003; Racine et al., 2013) and older people (Khan and Prior, 2010; Dukeshire et al., 2011; Knight, 2013) are more willing to buy local food. It was found that the enthusiasm for buying local food increases with age (Khan and Prior, 2010). In turn, another study proved (Bougherara et al., 2008) that younger representatives of richer households were more willing to purchase local food and to support initiatives promoting the local agriculture. Data on Polish consumers suggests that local food sold indirectly (in specialized stores) is mainly purchased by young and middle-aged high-income consumers (Radzymińska, 2016). It was also shown that the support for local initiatives through purchase of local food might be related to church attendance and marital status (Bellows et al., 2010; Marenick et al., 2010).

The results of this study suggest that market information on local products in insufficient. Therefore, there is a need for initiating marketing communication to trigger positive emotions linked to local food. A marketing message should be created based on qualitative values of local food, and should refer to environmental aspects of local food distribution and production.

\section{CONCLUSIONS}

From the perspective of regional economy, the development of local food systems and short supply chains is essential because of economic, environmental and social benefits. Further expansion of local food systems requires the engagement of and a collaborative partnership between public and private sector actors. Moreover, it is important to improve legal regulations intended to support small food producers, and to enable them to benefit from the support offered as a part of financial instruments.

Measures developed and implemented to increase the availability and supply of local food products should be harmonized with consumer expectations. Survey results showed that when describing local food, young consumers referred to socio-economic benefits linked to its manufacturing. They paid less attention to the specific attributes of food products and to environmental benefits of their production and distribution, which might suggest that measures taken to promote those products were poorly effective. The new generation of consumers and the emerging new technologies require new means and forms of communication. A customized communication, highlighting the benefits resulting from the consumption of local foods (especially within the range of their values), focusing on sustainable, humanitarian production and on reducing transport distances, is an important aspect of building consumer awareness and trust in local foods.

The limitation of this paper is that the research concentrates on young consumers only. Hence, caution should be exercised when generalizing these findings in different contexts. This study is about the perception of local food by young consumers; it does not cover any barriers to consumption, factors in choosing local food or expectations related to the production and distribution of local food. Further research should focus on identifying the determinants and demand constraints of this food category.

\section{SOURCE OF FINANCING}

Statutory Research Fund of the Faculty of Food Science, University of Warmia and Mazury in Olsztyn.

\section{REFERENCES}

Adams, D. C., Salois, M. J. (2010). Local versus organic: A turn in consumer preferences and willingness-to-pay. Renew. Agr. Food Syst., 25(4), 331-341.

Arsil, P., Li, E., Bruwer, J., Lyons, G. (2014). Exploring consumer motivations towards buying local fresh food products A means-end chain approach. Brit. Food J., 116(10), $1533-1549$.

Bellows, A. C., Alcaraz, G. V., Hallman, W. K. (2010). Gender and food, a study of attitudes in the USA towards organic, local, U.S. grown, and GM-Free foods. Appetite, 55(3), 540-550.

Blake, M. K., Mellor, J., Crane, L. (2010). Buying local food: Shopping practices, place, and consumption networks in defining food as "local”. Ann. Assoc. Am. Geogr., 100(2), 409-426.

Bougherara, D., Grolleau, G., Mzoughi, N. (2008). Buy local, pollute less. What drives households to join a community supported farm?. Ecol. Econ., 68(5), 1488-1495.

Brown, C. (2003). Consumers' preferences for locally produced food: A study in southeast Missouri. Am. J. Altern. Agr., 18(4), 213-224. 
Radzymińska, M., Jakubowska, D. (2018). Local food systems, short supply chains and perception of local food by consumers: a review and quantitative research. J. Agribus. Rural Dev., 4(50), 435-444. http://dx.doi.org/10.17306/J.JARD.2018.00426

Brown, E., Dury, S., Holdsworth, M. (2009). Motivations of consumers that use local, organic fruit and vegetable box schemes in Central England and Southern France, Appetite, 53(2), 183-188.

Byker, C., Rose, N., Serrano, E. (2010). The benefits, challenges and strategies of adults following a local food diet. J. Agr. Food Syst. Comm. Dev., 1(1), 125-137.

Chambers, S., Lobb, A., Butler, L., Harvey, K., Traill, W. B. (2007). Local, national and imported foods: A qualitative study. Appetite, 49(1), 208-213.

Coley, D., Howard, M., Winter, M. (2009). Local food, food miles and carbon emissions: A comparison of farm shopand mass distribution approaches. Food Policy, 34(2), $150-155$

Commission Staff Working Document 2013 on various aspects of short food supply chains Accompanying the document Report from the Commission to the European Parliament and the Council on the case for a local farming and direct sales labelling scheme (2013). Brussels.

Chrzan, J. (2004). Slow Food: what, why, and to where? Food, Culture and Society. Int. J. Mult. Res., 7(2), 117-132.

Dukeshire, S., Garbes, R., Kennedy, C., Boudreau, A., Osborne, T. (2011). Beliefs, attitudes and propensity to buy locally produced food. J. Agr. Food Syst. Comm. Dev., 1(3), 19-29.

Edwards-Jones, G. (2010). Does eating local food reduce the environmental impact of food production and enhance consumer health? P. Nutr. Soc., 69, 582-591.

Edwards-Jones, G., Canals, L. M., Hounsome, N., Truninger, M., Koerber, G., Hounsome, B., Cross, P., York, E.H., Hospida, A., Plassmann, K., Harris, I. M, Edwards, R. T., Day, G. A. S, Tomos, A. D., Cowell, S. J., Jones, D. L. (2008). Testing the assertion that 'local food is best': the challenges of an evidence-based approach. Trends Food Sci. Tech., 19(5), 265-274.

Farmer, J. (2012). Leisure in living local through food and farming. Leisure Sci., 34(5), 490-495.

Follett, J. R. (2009). Choosing a food future: differentiating among alternative food options. J. Agr. Environ. Ethics, $22,31-51$.

Furmana, C. A., Papavasilioub, F. (2018). Scale and affect in the local food movement. Food Cul. Soc., 21(2), 180-195, doi: 10.1080/15528014.2018.1427926

Goszczyński, W., Knieć, W. (2010). Rolnictwo w sieci - alternatywne sieci produkcji i dystrybucji żywności [Agriculture in a Net - Alternative Agro-Food Networks]. Wieś Roln., 2(147), 49-64 [in Polish].

Goszczyński, W., Knieć, W. (2011). Strengthening Alternative Agro-food Networks in the Eastern European Countryside. East. Eur. Countryside, 17, 5-20.
Haas, R., Sterns, J., Meixner, O., Nyob, D. I., Traar, V. (2013). Do US consumers' perceive local and organic fooddifferently?. An analysis based on means - end chain analysis and word association. Int. J. Food Syst. Dynam., 4(3), 214-226.

Hendrickson, M. K., Heffernan, W. D. (2002). Opening Spaces through Relocalization: Locating Potential Resistance in the Weakness of the Global Food System. Sociol. Rural., 42(4), 347-369.

Heslop, L. A. (2007). Literature review of Canadian consumer attitudes and perceptions. A report to Agriculture and Agri-Food Canada. Consumer Analysis Section. http:// www.marquecanadabrand.agr.gc.ca/domestic-nationale/ pdf/6303-eng.pdf

Higgins, V., Dibden, J., Cocklin, C. (2008). Building alternative agri-food networks: Certification, embeddedness and agri-environmental governance. J. Rural Stud., 24(1), $15-27$.

Jokinen, P., Järvelä, M., Puupponen, A. (2009). Local food systems and rural sustainability initiatives by small scale rural entrepreneurs in Finland. Finnish J. Rural Res. Policy, 17(2), 5-20.

Jones, A. (2002). An environmental assessment of food supply chains: a case study on dessert apples. Environ. Manag., 30(4), 560-576.

Khan, F., Prior, C. (2010). Evaluating the urban consumer with regard to sourcing local food: A Heart of England study. Int. J. Consum. Stud., 34(2), 161-168.

Kieljan, K. (2015). Zagrody edukacyjne w promocji produktów lokalnych [Educational homesteads in the promotion of local products]. Centrum Doradztwa Rolniczego w Brwinowie Oddział w Krakowie, http://ksow.gov.pl/ uploads/tx_library/files/08_Zagrody_edukacyjne_w_promocji_produkt\%C3\%B3w_lokalnych.pdf [in Polish].

Kimura, A. H., Nishiyama, M. (2008). The chisan-chisho movement: Japanese local food movement and its challenges. Agr. Hum. Values, 25(1), 49-64.

Knight, A.J. (2013). Evaluating local food programs: The case of Select Nova Scotia. Eval. Prog. Plann., 36(1), 29-39.

Lypchuk, V. Lypchuk, N. (2014). Lokalne systemy żywnościowe [Local food systems]. Gosp. Reg. Turys. Stud. Mat., 13, 87-92 [in Polish].

Markuszewska, A., Prior, A., Strano, A., Bálint, B., Midoux, B., Bros, C., Koutsaftaki, Ch., Jochum, Ch., Buffet, Ch., McGlynn, D., del Bravo, F., Valtari, H., Czaja, J., Saalasto, P., Töyli, P, Kokovkin, R., Redman, M., Regragui Mazili, S., Silm, S., Watson, S., Leporati, S., Marran, T., Hudson, T. (2012). Local Food and Short Supply Chains. EU Rural Review. A Publication from the European Network for Rural Development. https://enrd.ec.europa.eu/ 
Radzymińska, M., Jakubowska, D. (2018). Local food systems, short supply chains and perception of local food by consumers: a review and quantitative research. J. Agribus. Rural Dev., 4(50), 435-444. http://dx.doi.org/10.17306/J.JARD.2018.00426

sites/enrd/files/fms/pdf/E8F24E08-0A45-F272-33FBA6309E3AD601.pdf

Marenick, N., Gooch, M., Felfel, A. (2010). Local food opportunities. Focusing on the consumer. Retrieved from: www. vcmtools.ca/pdf/Local\%20Food\%20091310.pdf

Marsden, T., Banks, J., Bristow, G. (2000). Food supply chain approaches: exploring their role in rural development. Sociol. Ruralis, 40(4), 424-438.

McEachern, M. G., Warnaby, G., Carrigan, M., Szmigin, I. (2010). Thinking locally, acting locally? Conscious consumers and farmers markets. J. Mark. Manage., 26(5/6), 395-412.

Megicks, P., Memery, J., Angell, R. (2012). Understanding local food shopping: unpacking the ethical dimension", J. Mark. Manag., 28(3/4), 264-289.

Memery, J., Angell, R. J., Megicks, P., Lindgreen, A. (2015). Unpicking motives to purchase locally-produced food: analysis of direct and moderation effects. Eur. J. Market., 49(7/8), 1207-1233.

Michalczyk, J. (2017). Znaczenie lokalnej żywności oraz krótkich łańcuchów dostaw w kształtowaniu zrównoważonego rozwoju rolnictwa i obszarów wiejskich w Unii Europejskiej [The importance of local food and short supply chains in shaping sustainable development of agriculture and rural areas in the European Union]. Ekon. Międzyn., 17, 5-20 [in Polish].

Morgan, K., Marsden, T., Murdoch, J. (2006). Worlds of Food. Place, Power and Provenance in the Food Chain. Oxford: Oxford University Press.

Mount, P. (2012). Growing local food: scale and local food systems governance. Agr. Hum. Val., 29, 107-121.

Murdoch, J., Marsden, T., Banks, J. (2000). Quality, Nature, and Embeddedness: Some Theoretical Considerations in the Context of the Food Sector. Econ. Geogr., 76(2), $107-125$.

Norberg-Hodge, H., Merrifield, T., Gorelick, S. (2002). Bringing the Food Economy Home: Local Alternatives to Global Agribusiness. London: Zed Books.

Norberg-Hodge, H., Merrifield, T., Gorelick, S. (2007). Lokalna żywność. Lokalne alternatywy dla korporacji rolnych [Bringing the Food Economy Home: Local Alternatives to Global Agribusiness]. Kraków: Wyd. Zielone Brygady [in Polish].

Nurse, G., Onozaka, Y., McFadden, D. T. (2010). Understanding the connections between consumer motivations and buying behavior: The case of the local food system movement. Selected Paper prepared for presentation at the Southern Agricultural Economics Association Annual Meeting, Orlando. Retrieved from: http://ageconsearch. umn.edu/bitstream/56494/2/SAEApaper_final_Nurse.pdf
Onozaka, Y., Mcfadden, D. T. (2011). Does local labeling complement or compete with other sustainable labels? A conjoint analysis of direct and joint values for fresh produce claims. Am. J. Agr. Econ., 93(3), 693-706.

Onozaka, Y., Nurse, G., McFadden, D. T. (2010). Local food consumers: how motivations and perceptions translate to buying behavior. Choic. Magazine Food Farm Res. Iss., 25(1), 1-6.

Opinion of the Committee of the Regions on "Local food systems" (outlook opinion) (2011). Offic. J. Eur. Union, C 104/1.

Pearson, D., Henryks, J., Trott, A., Jones, P., Parker, G., Dumaresq, D, Dyball, R. (2011). Local food: Understanding consumer motivations in innovative retail formats. Brit. Food J., 113(7), 886-899.

Penney, U., Prior, C. (2014). Exploring the urban consumer's perception of local food. Int. J. Ret. Dist. Manag., 42(7), 580-594.

Polimeni, J. M., Shirey, R. L., Trees, Ch. L. (2006). The Demand For Community Supported Agriculture. J. Bus. Econom. Res., 4(2), 49-59.

Psarikidou, K., Szerszynski, B. (2012). Growing the social: alternative agrofood networks and social sustainability in the urban ethical foodscape. Sust. Sci. Prac. Policy, 8(1), 30-39.

Racine, E. F., Mumford, E. A., Laditka, S. B., Lowe, A. E. (2013). Understanding characteristics of families who buy local produce. J. Nutr. Edu. Behav., 45(1), 30-38.

Radzymińska, M. (2016). Konsument na rynku żywności lokalnej - studium empiryczne [A consumer at the local food market - an empirical study]. Wydawnictwo UWM, Olsztyn 2016 [in Polish].

Rogala, A. (2014). Czynniki wpływające na zakupy żywności lokalnej [Factors influencing the purchases of local food]. Market. Ryn., 6(CD), 633-646 [in Polish].

Rogala, A. (2015). Współczesna konsumpcja żywności w pułapce paradoksu postmodernistycznego świata [Modern food consumption - trapped in the paradox of postmodern world]. J. Agr. Rural Dev., 3(37), 513-520 [in Polish].

Roininen, K., Arvola, A., Lähteenmäki, L. (2006). Exploring consumers' perceptions of local food with two different qualitative techniques: Laddering and word association. Food Qual, Prefer., 17, 20-30.

Schönhart, M., Penker, M., Schmid, E. (2008). Sustainable local food production and consumption: Challenges for implementation and research. $8^{\text {th }}$ European IFSA Symposium, 6-10 July 2008,

Selfa, T., Qazi, J. (2005). Place, taste, or face to face? Understanding producer - Consumer networks in "local" food 
Radzymińska, M., Jakubowska, D. (2018). Local food systems, short supply chains and perception of local food by consumers: a review and quantitative research. J. Agribus. Rural Dev., 4(50), 435-444. http://dx.doi.org/10.17306/J.JARD.2018.00426

systems in Washington State. Agr. Hum, Values, 22(4), 451-464.

Seyfang, G. (2007). Cultivating carrots and community: local organic food and sustainable consumption. Env. Val., $16(1), 105-123$.

Storper, M., Salais, R. (1997). Worlds of production: The action frameworks of the economy. Cambridge, MA: Harvard University Press.

Wiśniewska, M. (2012). Żywność, życie i turystyka w stylu „slow” [Food, life and tourism in "slow" style]. Zarz. Fin., 3(2), 161-176 [in Polish].
Żakowska-Biemans, S., Ozimek, I., Szlachciuk, J., Matusiak, K. (2017). Czynniki wpływające na rozwój lokalnej produkcji i dystrybucji żywności w opinii konsumentów [Factors determining production and distribution of local food in the opinion of consumers]. Handel Wewn., 4(369), 357-369 [in Polish]. 